\title{
Biological activity of some essential oil constituents in four Nepeta L. species against Sitophilus oryzae L.
}

\author{
SHAHLA AMINI, MAJID GHORBANI NOHOOJI, MOUSA KHANI", MOHAMMAD REZA LABBAFI, \\ FARAHNAZ KHALIGHI-SIGAROODI \\ Medicinal Plants Research Center, Institute of Medicinal Plants, ACECR, 55th Kilometer of Tehran-Qazvin Freeway, Karaj, Iran \\ Tel: +98-26-34764010-19, Fax: +98-26-34764021, `email: khanimousa@yahoo.com, khani@imp.ac.ir
}

Manuscript received: 27 August 2018. Revision accepted: 12 January 2019.

\begin{abstract}
Amini S, Nohooji MG, Khani M, Labbafi MR, Khalighi-Sigaroodi f. 2019. Biological activity of some essential oil constituents in four Nepeta L. species against Sitophilus oryzae L.. Biodiversitas 20: 338-343. Recently, there has been a growing interest in research concerning the possible use of plant extracts as alternatives to synthetic insecticides. Essential oils are among the best-known natural substances with insecticidal properties. These compounds may act as fumigants, contact insecticides, repellents, antifeedants and may affect growth and development of the insects. In an attempt to find a natural and inexpensive method for the control of stored-product pests, contact toxicity of essential oils of Nepeta cataria, Nepeta pogonosperma, Nepeta glomerulosa. and Nepeta binaloudensis. were investigated on adult insects of Sitophilus oryzae L. (Coleoptera, Curculionidae) in vitro condition. Chemical Composition, repellency and fumigant toxicity of the essential oils were investigated. Chemical composition of the essential oils of above plants were identified by GC-MS. $4 a \alpha, 7 \alpha, 7 a \beta$-nepetalactone (82.74\%) was major component of $N$. cataria and also different isomers of nepetalactone were among the major compounds in N. Pogonosperma and N. binaloudensis oils. In fumigants bioassay, $N$. glomerulosa $(124.318 \mu \mathrm{L} / \mathrm{L}$ air) showed the highest toxicity against $S$. oryzae adults, followed by $N$.pogonosperma $(150.49 \mu \mathrm{L} / \mathrm{L}$ air) and $N$. cataria $(152.630 \mu \mathrm{L} / \mathrm{L}$ air), respectively. Also, the $S$. oryzae was repelled by $N$. cataria $(91.61 \%)$ and $N$. binaloudensis $(91.50 \%)$, respectively.
\end{abstract}

Keywords: Fumigant toxicity, Nepeta binaloudensis, Nepeta cataria, Nepeta glomerulosa, Nepeta pogonosperma, Sitophilus oryzae

\section{INTRODUCTION}

The rice weevil, Sitophilus oryzae L. is a serious insect pest of stored cereals all around the world. They attack wheat, corn, rice, oats, rye, barley, dried beans, sorghum and cereal products, especially macaroni. Females deposit the eggs within seed grains or its products. So $S$. oryzae is considered a major and cosmopolitan insect pest because of adults (male and female) and larvae are insatiable feeders and vary of grains mass. (Park et al. 2003; Kim et al. 2016).

In the past two decades, the control of insects in storedfood products relies heavily upon the use of gaseous fumigants and residual insecticides, both of which pose serious hazards to warm-blooded animals and the environment. Various methods were using in control of stored product pests. Use of synthetic fumigant materials such as methyl bromide $(\mathrm{MeBr})$ and phosphine (PH3) are the most widespread and famous methods throughout the world. The use of methyl bromide has been restricted in most developed countries duo to its ozone-depleting properties in the atmosphere since 2005. It is still applied exceptionally in emergency situations and for quarantine purposes only. Nowadays, phosphine is regarded as the major chemical control agent of stored pests as fumigant. But long period usage of this chemical comes with some destructive effects and problems. Toxicity and effect on of mammals and other non-target organisms, Pest resistance, residue problems and decrease in natural enemies are the most observed problems in this viewpoint. Therefore natural products are generally preferred in compare with chemical ones because of less harmful compounds and their biodegradability (Prabakar and Jebanesan 2004).

Plants have acquired effective defense mechanisms that ensure their survival under adverse environmental factors (Prakash and Rao 1997). One of the main components of herbal extracts which have insecticidal effect is essential oils (EOs). Essential oil is one of the most active components of medicinal and aromatic plants which can be extracted from different parts of plants (Kim et al. 2013). Essential oils are easily produced by distillation of plant material and contain many volatile and low-molecularweight terpenes and phenols (Regnault-Roger et al. 2012). In some Asian and African countries, essential oils are traditionally used through fumigant or contact action to protect grains against storage pests, a suitable method to preserve products stored in warehouses and on small farms (Shaaya et al. 1997; Mahmoudvand et al. 2011).

The Lamiaceae (Labiatae) family (mint family) is one of the most diverse and widespread plant families of flowering plants in terms of ethnomedicine and its medicinal value is based on the presence of volatile essential oils. (Sarac and Ugur 2007). The mint family is one of the largest families among the dicotyledonous plants while many genera and species are highly aromatics, due to the presence of external glandular structures that produce volatile oil. Among them, the genus Nepeta is one of the largest genera in Lamiaceae family. The genus name originates from an ancient Etruscan city (Mozaffarian 
1998). There are about 250 species. The genus is broadly native to Europe, Asia, and Africa, and has also naturalized in North America and many other regions all around the world. In Iran exists more than 75 species through the country (Giuliani and Maleci 2008; Jamzad 2012).

The genus comprise of both perennial and annual species. They are distinguishable with erect stems along with opposite heart-shaped and green to gray-green leaves. They are usually known as aromatic plants due to presence of Essential oils (EOs) in their herbaceous aerial parts. So they are important agents which used in different pesticide, pharmaceutical, flavoring, perfumery, fragrance and cosmetic industries (Ozkan 2008). On the other hand medicinal plants are so important in rural and tribal lives of the developing countries because of their socio-cultural, spiritual and medicinal use (Hendawy et al. 2010). Numerous Plant species (between 50,000 to 80,000) were used by human kind for medicinal purposes. Insofar as today it is estimated that medicinal and aromatic plants are known for $70 \%-80 \%$ of global population for their medicinal and therapeutic effects (WHO 2008; Venkateshappa and Sreenath 2013).

In this context, the present study aims to evaluate the insecticidal effect of essential oils of Nepeta cataria L., Nepeta pogonosperma Jamzad \& Assadi, Nepeta glomerulosa Boiss. and Nepeta binaloudensis Jamzad. (Lamiaceae) species on the rice weevil, Sitophilus oryzae (L).

\section{MATERIALS AND METHODS}

\section{Insect rearing}

Colonies of rice weevil were obtained from Agricultural Entomology Research Department of Iranian Research Institute of Plant Protection (Tehran-Iran). Colonies were reared on whole rice grains in plastic container in the laboratory, where all experiments were conducted $(27 \pm$ $1{ }^{\circ} \mathrm{C}, 75 \pm 5 \%$ R.H. and 12: 12 h L: D) (Rahman and Talukder 2006). The adult rice weevils, which were used in the experiments were 7-14 days old (Khani et al. 2012).

\section{Plant material}

Distribution pattern of four species of genus Nepeta $(N$. cataria, N. pogonosperma, $N$. glomerulosa and $N$. binaloudensis) were evaluated on the country map and then the collection process of plants was done during vast different filed works. The aerial parts of four Nepeta species were collected in full flowering stage from their natural habits in Iran. They were transmitted to the herbarium and after pressing and desiccation they were fixed on the standard herbarium sheets. In the next stage, the collected plants were identified using valuable floras of the country such as Flora Iranica and Flora of Iran (Rechinger et al. 1982, Jamzad 2012 and related adjacent regions. Voucher specimens have been deposited in the Herbarium of Medicinal Plants Research Center of Iran (IMPH). Detail information of studied species is presented in Table 1. The aerial parts of the all collected plants were dried in the shadow at room temperature $\left(24^{\circ} \mathrm{C}\right)$ and before the extraction of essential oils, they were ground to the fine powder using a grinder.

\section{Isolation procedure}

Powders of air-dried aerial parts of the plants (100 g) were subjected to hydro-distillation for $3 \mathrm{~h}$ using a Clevenger-type apparatus (Khani et al. 2017). Anhydrous sodium sulfate was used to remove water. Extracted essential oil was stored in sealed vials at $4{ }^{\circ} \mathrm{C}$ until application in the experiments.

\section{GC-MS analysis of essential oils}

The GC-MS analyses were carried out in center of professional analysis in Medicinal Plants Research Center, Institute of Medicinal Plants, ACECR, Karaj, IRAN to determine the different components of the volatile oils.

The essential oils were also analyzed by an Agilent 6890 apparatus on capillary column BP-5MS (see GC). Mass Spectrometry (Agilent 5973) were done in electronic impact mode (70 eV), split injection ratio (1: 50) and mass range of 40 to $500 \mathrm{amu}$. Retention indices were calculated by using retention times of n-alkanes $(\mathrm{C} 8-\mathrm{C} 20)$ that were injected at the same temperature and conditions. Compounds were identified by comparing retention indices (RI) with those reported in the literature and their mass spectrum with Wiley library (Adams 2007; McLafferty and Stauffer 1989).

\section{Fumigant toxicity}

To evaluate the fumigant toxicity effects of EOs extracted from $N$. cataria, $N$. pogonosperma, $N$. glomerulosa and $N$. binaloudensisa against adult rice weevil, the EOs with volumes of 5, 10, 15, 20, 25 and 30 $\mu \mathrm{L}$ were dissolved in $1 \mathrm{~mL}$ acetone to obtain dosages of $71.5,143,214,286,357$ and $428.5 \mu \mathrm{L} / \mathrm{L}$ of air, respectively (Khani et al. 2017). Treatments and acetone as control were applied on Whatman filter papers that were $2 \mathrm{~cm}$ in diameter. When the applied solvent evaporated in $15 \mathrm{~m}$, the treated filter papers were attached inside screw caps of 70$\mathrm{ml}$ glass vials (Khani et al. 2017) with rice grains, then were followed by releasing 15 adults insects. The caps were tightly screwed on and the vials were sealed with parafilm. Each treatment and control had five replications. To determine $\mathrm{LC}_{50}$ (The concentration of the Treatments such as EOs that kills $50 \%$ of the test insects during the observation period), the mortality was recorded 72 hours after treatment (Negahban et al. 2006, Negahban and Moharramipoor 2007).

Table 1. Localities and elevation of studied Nepeta species

\begin{tabular}{lll}
\hline Species & Locality & Elevation \\
\hline N. cataria & $\begin{array}{l}\text { Mazandaran province, } \\
\text { Siahbisheh }\end{array}$ & $2300 \mathrm{~m}$ \\
N. pogonosperma & Qazvin province, Alamout & $3000 \mathrm{~m}$ \\
N. glomerulosa & $\begin{array}{l}\text { Kerman province, Jirof, Deh- } \\
\text { bakri }\end{array}$ & $2260 \mathrm{~m}$ \\
N. binaloudensis & $\begin{array}{l}\text { Khorasan Razavi Province, } \\
\text { Neishabour }\end{array}$ & $1662 \mathrm{~m}$ \\
\hline
\end{tabular}




\section{Repellency}

The repellency test was conducted based on McDonald et al. (1970) in glass Petri dish $(9 \mathrm{~cm}$ in diameter and $1 \mathrm{~cm}$ high) which contained a $9-\mathrm{cm}$ filter paper. The EOs of $N$. cataria, $N$. pogonosperma, $N$. glomerulosa and $N$. binaloudensis were diluted in acetone to prepare different concentrations $\left(10,15,20\right.$ and $\left.25 \mu \mathrm{L} / 30 \mathrm{~cm}^{2}\right)$. Pure acetone was used as the control. The filter paper was cut in half. One $\mathrm{mL}$ of each concentration was uniformly applied to one half of the filter paper (Negahban et al. 2006, Negahban and Moharramipoor 2007). The other half (control) were treated with $1 \mathrm{ml}$ of $100 \%$ acetone. Then, both papers were air dried to completely evaporate the solvent. Papers were attached to each other with a paper adhesive tape. 15 adults were released at the center of each filter-paper disc and a cover was placed over the Petri dish $\left(27 \pm 1^{\circ} \mathrm{C}, 75 \pm 5 \%\right.$ R.H. and 12: 12 h L: D). Each treatment was replicated four times. The number of insects present on the control and treated regions was hourly recorded up to 5 hours after treatment. Mean number of insects present on the control (NC) and treated (NT) regions during the experiment was used to estimate the percent of repellency (PR) which were equal to (NC-NT)/ $(\mathrm{NC}+\mathrm{NT}) \times 100$ (Obeng-Ofori and Reichmuth 1997; Ogendo et al. 2008). All negative percent repellency (PR) values were considered as zero.

\section{Data analysis}

The Polo-Plus software was used to estimate the mortality rate and lethal concentration of essential oils (Robertson et al. 2003). Percentage of insect mortality was calculated by probit analysis (Finney 2006). Data of repellency test and nutritional indices were analyzed using procedures of SAS ${ }^{\circledR}$ (SAS Institute Inc. 2002) based on a completely randomized design. The normality of the transformed and untransformed data and also normality of residuals after analysis of variance were checked using stem-leaf and normal probability plots. Homoscedasticity was checked by observing graphical distribution plots of variance by mean (PROC PLOT). Data were square-root transformed. A general linear model for analysis of variance (PROC GLM) was used to compare treatments. Comparisons among treatments were made using the Tukey test where analysis of variance showed significant differences among means. In all experiments, differences between treatments were considered significant at $P<0.05$ and mean values are given as the mean $\pm \mathrm{SD}$.

\section{RESULTS AND DISCUSSION}

\section{Fumigant toxicity}

$L_{50}$ values of $N$. cataria, $N$. pogonosperma, $N$. glomerulosa and $N$. binaloudensis essential oils against adult rice weevil were evaluated after $72 \mathrm{~h}$. As the results shown in Table 2 they were 152.630, 150.49, 124.318 and $366.80 \mu \mathrm{L} / \mathrm{L}$ air for studied species, respectively. Results indicated that $N$. glomerulosa had the highest toxicity and $N$. binaloudensis had the lowest toxicity against $S$. oryzae adults (Table 2).

\section{Repellency}

The results of repellency tests of essential oils of $N$. cataria, $N$. pogonosperma, $N$. glomerulosa and $N$. binaloudensis against $S$. oryzae insects after 5 hours are shown in Table 3. The results showed that all four species had repellency effect with an increase in concentration, so the maximum repellency was related to the highest concentration. Two species, $N$. cataria and $N$. Binaloudensis, at the highest concentration $(25 \mu \mathrm{l} / 30 \mathrm{~cm} 2)$ had $100 \%$ repellency and the average repellency percentage for both species was $91.61 \%$ and $91.51 \%$ respectively that these species had the same value for repellency. The lowest percentage of repellency was related to $N$. glomerulosa with an average repellency of $46.11 \%$. Also in these species, with increasing the time, the percentage of repellency increased.

\section{Essential oils composition}

Three isomers of nepetalactones: $4 a \alpha, 7 \alpha, 7 a \beta$ -

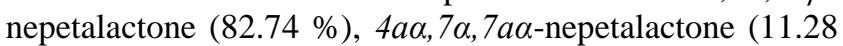
$\%)$ and $4 a \alpha, 7 \beta, 7 a \alpha$-nepetalactone $(4.14 \%)$ contained more than $98 \%$ of essential oil of $N$. cataria. While in $N$. pogonosperma one isomer of Nepetalalactone: $4 a-\alpha, 7 \alpha$, $7 a \alpha$-Nepetalalactone, was found that constituent $6.20 \%$ of oil compositions. Also no isomers of nepetalactone existed in oil of $N$. glomerulosa. However, the major compound of its oil was 1,8-cineole (23.34\%). The essential oil of $N$. binaloudensis has three isomers of Nepetalactone: $4 a$ $\alpha, 7 \alpha, 7 a \beta$-nepetalactone $\quad(23.46 \%), \quad 4 a \alpha, 7 \alpha, 7 a \alpha-$ nepetalactone $(1.09 \%)$ and $4 a \alpha, 7 \beta, 7 a \alpha-n e p e t a l a c t o n e ~(0.6)$ which made more than $25 \%$ of oil compositions of the studied species.

Table 2. Fumigant toxicity of the essential oils extracted from four Nepeta species against adult rice weevil, Sitophilus oryzae, in vitro after $72 \mathrm{~h}$ from treatment

\begin{tabular}{|c|c|c|c|c|}
\hline Essential oils & $\begin{array}{c}\mathbf{L C}_{50} \\
(\mu \mathrm{L} / \mathrm{L} \text { air })\end{array}$ & $\begin{array}{c}\mathrm{LC}_{95} \\
(\mu \mathrm{L} / \mathrm{L} \text { air }) \\
\end{array}$ & Chi-square & Heterogeneity \\
\hline N. cataria & $\begin{array}{l}152.630 \\
(143.304-161.383)\end{array}$ & $\begin{array}{l}263.371 \\
(244.529-288.796)\end{array}$ & 2.865 & 0.716 \\
\hline N. pogonosperma & $\begin{array}{l}150.49 \\
(124.35-173.74)\end{array}$ & $\begin{array}{l}293.97 \\
(243.15-420.72)\end{array}$ & 4.92 & 1.229 \\
\hline N. glomerulosa & $\begin{array}{l}124.318 \\
(104.61-142.47)\end{array}$ & $\begin{array}{l}369.95 \\
(308.39-481.23)\end{array}$ & 5.89 & 1.474 \\
\hline N. binaloudensis & $\begin{array}{l}366.80 \\
(324.81-349.60)\end{array}$ & $\begin{array}{l}514.67 \\
(478.97-567.42)\end{array}$ & 1.43 & 0.358 \\
\hline
\end{tabular}


Table 3. Repellency percentage of the essential oils extracted from four Nepete species against adult rice weevil, S. oryzae

\begin{tabular}{|c|c|c|c|}
\hline Essential oils & $\begin{array}{c}\text { Concentration } \\
\left(\mu \mathrm{L} / 30 \mathrm{~cm}^{2}\right)\end{array}$ & Time (h) & $\begin{array}{c}\text { Repellency } \\
(\%)\end{array}$ \\
\hline N. cataria & 10 & 1 & 86.67 \\
\hline N. cataria & 10 & 2 & 90.00 \\
\hline N. cataria & 10 & 3 & 93.34 \\
\hline N. cataria & 10 & 4 & 96.67 \\
\hline N. cataria & 10 & 5 & 96.67 \\
\hline N. cataria & 15 & 1 & 66.67 \\
\hline N. cataria & 15 & 2 & 75.56 \\
\hline N. cataria & 15 & 3 & 86.67 \\
\hline N. cataria & 15 & 4 & 96.67 \\
\hline N. cataria & 15 & 5 & 100.00 \\
\hline N. cataria & 20 & 1 & 76.67 \\
\hline N. cataria & 20 & 2 & 90.00 \\
\hline N. cataria & 20 & 3 & 96.67 \\
\hline N. cataria & 20 & 4 & 96.67 \\
\hline N. cataria & 20 & 5 & 96.67 \\
\hline N. cataria & 25 & 1 & 86.67 \\
\hline N. cataria & 25 & 2 & 100.00 \\
\hline N. cataria & 25 & 3 & 100.00 \\
\hline N. cataria & 25 & 4 & 100.00 \\
\hline N. cataria & 25 & 5 & 100.00 \\
\hline N. pogonosperma & 10 & 1 & 31.67 \\
\hline N. pogonosperma & 10 & 2 & 40.00 \\
\hline N. pogonosperma & 10 & 3 & 70.00 \\
\hline N. pogonosperma & 10 & 4 & 80.00 \\
\hline N. pogonosperma & 10 & 5 & 83.34 \\
\hline N. pogonosperma & 15 & 1 & 16.67 \\
\hline N. pogonosperma & 15 & 2 & 40.00 \\
\hline N. pogonosperma & 15 & 3 & 70.00 \\
\hline N. pogonosperma & 15 & 4 & 83.34 \\
\hline N. pogonosperma & 15 & 5 & 90.00 \\
\hline N. pogonosperma & 20 & 1 & 25.00 \\
\hline N. pogonosperma & 20 & 2 & 56.67 \\
\hline N. pogonosperma & 20 & 3 & 80.00 \\
\hline N. pogonosperma & 20 & 4 & 90.00 \\
\hline N. pogonosperma & 20 & 5 & 93.34 \\
\hline N. pogonosperma & 25 & 1 & 36.67 \\
\hline N. pogonosperma & 25 & 2 & 90.00 \\
\hline N. pogonosperma & 25 & 3 & 90.00 \\
\hline N. pogonosperma & 25 & 4 & 96.67 \\
\hline N. pogonosperma & 25 & 5 & 96.67 \\
\hline N. glomerulosa & 10 & 1 & 43.33 \\
\hline N. glomerulosa & 10 & 2 & 36.67 \\
\hline N. glomerulosa & 10 & 3 & 50.00 \\
\hline N. glomerulosa & 10 & 4 & 33.34 \\
\hline N. glomerulosa & 10 & 5 & 49.05 \\
\hline N. glomerulosa & 15 & 1 & 36.67 \\
\hline N. glomerulosa & 15 & 2 & 36.67 \\
\hline N. glomerulosa & 15 & 3 & 26.67 \\
\hline N. glomerulosa & 15 & 4 & 23.34 \\
\hline N. glomerulosa & 15 & 5 & 26.67 \\
\hline N. glomerulosa & 20 & 1 & 53.34 \\
\hline N. glomerulosa & 20 & 2 & 43.33 \\
\hline N. glomerulosa & 20 & 3 & 70.00 \\
\hline N. glomerulosa & 20 & 4 & 60.00 \\
\hline N. glomerulosa & 20 & 5 & 53.33 \\
\hline N. glomerulosa & 25 & 1 & 83.33 \\
\hline N. glomerulosa & 25 & 2 & 23.33 \\
\hline N. glomerulosa & 25 & 3 & 60.00 \\
\hline N. glomerulosa & 25 & 4 & 43.34 \\
\hline N. glomerulosa & 25 & 5 & 70.00 \\
\hline N. binaloudensis & 10 & 1 & 86.67 \\
\hline
\end{tabular}

\begin{tabular}{|c|c|c|c|}
\hline N. binaloudensis & 10 & 2 & 90.00 \\
\hline N. binaloudensis & 10 & 3 & 93.34 \\
\hline N. binaloudensis & 10 & 4 & 96.67 \\
\hline N. binaloudensis & 10 & 5 & 96.67 \\
\hline N. binaloudensis & 15 & 1 & 66.67 \\
\hline N. binaloudensis & 15 & 2 & 73.33 \\
\hline N. binaloudensis & 15 & 3 & 86.67 \\
\hline N. binaloudensis & 15 & 4 & 96.67 \\
\hline N. binaloudensis & 15 & 5 & 100.00 \\
\hline N. binaloudensis & 20 & 1 & 76.67 \\
\hline N. binaloudensis & 20 & 2 & 90.00 \\
\hline N. binaloudensis & 20 & 3 & 96.67 \\
\hline N. binaloudensis & 20 & 4 & 96.67 \\
\hline N. binaloudensis & 20 & 5 & 96.67 \\
\hline N. binaloudensis & 25 & 1 & 86.67 \\
\hline N. binaloudensis & 25 & 2 & 100.00 \\
\hline N. binaloudensis & 25 & 3 & 100.00 \\
\hline$N$. binaloudensis & 25 & 4 & 100.00 \\
\hline N. binaloudensis & 25 & 5 & 100.00 \\
\hline
\end{tabular}

\section{Discussion}

In the current research, the potential of repellency and fumigant toxicity of essential oils from four Nepeta species of Iran were examined. Essential oil in the genus Nepeta composed of many compounds that have various biological activities. The Results demonstrate that the highest toxicity against $S$. Oryzae in fumigants bioassay was observed in N. Glomerulosa $(124.318 \mu \mathrm{L} / \mathrm{L}$ air) and N.pogonosperma with concentration of $150.49 \mu \mathrm{L} / \mathrm{L}$ air and $N$. cataria with $152.630 \mu \mathrm{L} / \mathrm{L}$ air have high toxicity power respectively. Also, the $S$. oryzae was repelled by $N$. cataria $(91.61 \%)$ and $N$. binaloudensis $(91.50 \%)$, respectively. $4 a \alpha, 7 \alpha, 7 a \beta$ nepetalactone $(82.74 \%)$ was major component of $N$. cataria and also different isomers of nepetalactone were among the major compounds in N. Pogonosperma and $N$. binaloudensis oils.

Asgarpanah et al. (2014) have reported that nepetalactones, iridoids and respective glucosides, diterpenes, triterpenes and flavonoids are main compounds of different Nepeta taxa (Asgarpanah et al. 2014). Moreover, most of the Nepeta species consider as good sources for production of essential oils and also organic extracts having a broad spectrum of biological activities such as insecticidal effects (Calmasur et al. 2006).

These authors detected that $N$. cataria and $N$. binaloudensis had highest repellency that $4 a-\alpha, 7 \alpha, 7 a \alpha-$ Nepetalalactone and 1,8-cineole were their major EOs constituents respectively. while the lowest one was related to $N$. glomerulosa. It seems that essential oil of both $N$. cataria and $N$. binaloudensis have special compounds of nepetalactones that showed high level of repellency. Analysis of essential oil showed that these species have three isomers of Nepetalactone consists of $4 a \alpha, 7 \alpha, 7 a \beta$ nepetalactone, $4 a \alpha, 7 \alpha, 7 a \alpha$-nepetalactone and $4 a \alpha, 7 \beta, 7 a \alpha-$ nepetalactone. These isomers have constituted more than $97 \%$ and $25 \%$ of essential oils respectively. These findings are in good agreement with previous investigations on the species. In Adiguzel et al. (2009) research, was studied the essential oil of Nepeta cataria and it was identified 22 
compounds, dominantly $4 a \alpha, 7 \alpha, 7 a \beta$-nepetalactone (70.4\%), $\quad 4 a \alpha, 7 \alpha, 7 a \alpha$-nepetalactone $\quad(6.0 \%) \quad$ and $4 a \beta, 7 \alpha, 7 a \beta$-nepetalactone $(2.5 \%)$. In similar study was detected that essential oil of $N$. binaludensis contained $4 a \alpha$, $7 \alpha, 7 a \alpha$-nepetalactone $(19 \%)$ as one of the main compounds (Mohammadpour et al. 2013).

Authors also detected that the repellency of $N$. pogonosperma was lower than $N$. cataria and $N$. binaloudensis, but was more higher than $N$. glomerulosa. While, no isomer of nepetalactone were found in oil composition of $N$. glomerulosa. The essential oil analysis of $N$. pogonosperma proved that one isomer of Nepetalalactone, $4 a-\alpha, 7-\alpha, 7 a-\alpha$-Nepetalalactone, existed in essential oil that constituted $6.20 \%$ of the oil. Likewise, Ali et al. (2012) founded $4 a \alpha, 7 \alpha, 7 a \alpha$-nepetalactone $(14.5 \%)$ as one of the main compounds in the oil of $N$. Pogonosperma. Our results are relatively in agreement with this research.

Previous studies have revealed that the Nepeta species have been divided into two groups based on the composition of main parts of essential oils. The first group contains various isomers of nepetalactone and the second one has other compounds such as 1, 8-cineole, $\beta$ caryophyllene and etc. (Bates and Sigel 1963). These authors have believed that the high level of repellency in species is due to existence of different isomers of nepetalactone. Therefore the obtained results are in strong accordance with this fact.

Nepetalactone is an organic compound, first isolated from $N$. cataria, which acts as a cat attractant. It is a bicyclic monoterpenoid, and has ten carbons that derived from isoprene with two fused rings: a cyclopentane and a lactone. This compound belongs to the class of iridoids. The structure and the effects of this compound are like to those of valepotriates. In this study area, some isomers of nepetalactone are known (Bates and Sigel 1963).

Some studies such as Schultz et al. (2004) have confirmed that the nepetalactones are of great interest owing to their potential application as aphid sex pheromones and also insect repellents (Schultz et al. 2004).

The authors reported that the essential oil of $N$. glomerulosa had highest level of fumigant toxicity against $S$. oryzae adults. The oil of this species riches of $1,8-$ cineole, while reverse pattern was seen in oil of other species. It seems that this toxicity is due to presence of highest amount of 1,8-cineole. Cineole or 1,8-cineole (eucalyptol) are monoterpene oxides exist in the essential oil of many aromatic plants such as Eucalyptus spp. This compound has many biological activities which popularly used to treat respiratory diseases aggravated by infection (Santos et al. 2004). The obtained results agreed with previous studies. For example, Abdelgaleil et al. (2009) have reported high level of 1-8-cineole toxicity against $S$. oryzae. The essential oil composition of the species and its toxicity against the rice weevil are in concordance with the results of this study. It seems that the essential oils of different species of genus Nepeta which is wildly distributed in Iran are suitable cases for preventing and controlling of insect pests in order to conservation of stored-food products.

\section{ACKNOWLEDGEMENTS}

This work was funded by the Iranian Academic Center for Education, Culture and Research (ACECR) [grant number 2350-20]. The institute was appreciated for the support. We also would like to thank the Agricultural Entomology Research Department of Iranian Research Institute of Plant Protection for providing the colonies of rice weevil.

\section{REFERENCES}

Abdelgaleil SAM, Mohamed MIE, Badawy MEI, El-arami SAA..2009. Fumigant and contact toxicities of monoterpenes to Sitophilus oryzae (L.) and Tribolium castaneum (Herbst) and their inhibitory effects on acetylcholinesterase activity. J Chem Ecol 35: 518-525.

Adams RP. 2007. Identification of essential oil components by gas chromatography/mass spectrometry. Allured Publishing Corporation: Carol Stream, Texas.

Adiguzel A, Ozer H, Sokmen M, Gulluce M, Sokmen A, Kilic H, Sahin F, Baris O. 2009. Antimicrobial and antioxidant activity of the essential oil and methanol extract of Nepeta cataria. Pol J Microbiol 58 (1): 69-76.

Ali T, Javan M, Sonboli A, Semnanian S. 2012. Evaluation of the antinociceptive and anti-inflammatory effects of essential oil of Nepeta pogonosperma Jamzad et Assadi in rats. DARU J Pharm Sci 20 (1): 48.

Asgarpanah J, Sarabian S, Ziarati P. 2014. Essential oil of Nepeta genus (Lamiaceae) from Iran: A review. J Essential Oil Res 26: 1-12.

Bates RB, Sigel CW. 1963. "Terpenoids. Cis-trans-and trans-cisNepetalactones". Experientia 19 (11): 564-565.

Calmasur O, Aslan I, Sahin F. 2006. Insecticidal and acaricidal effect of three Lamiaceae plant essential oils against Tetranychus urticae Koch and Bemisia tabaci Genn. Ind Crops Prod. 23: 140-146.

Finney DJ. 2006. Probit Analysis. Cambridge University Press, London.

Giuliani C, Maleci Bini L. 2008. Insight into the structure and chemistry of glandular trichomes of Labiatae, with emphasis on subfamily Lamioideae. Plant Syst Evol. 276: 199-208.

Hendawy SF, Ezz ED, Aziz A, Omer E. 2010. Productivity and oil quality of Thymus vulgaris L. under organic fertilization conditions. Ozean J. Appl. Sci 3: 203-216.

Jamzad Z. 2012. Flora of Iran. Research Institute of forest and rangelands. Tehran, Iran. [Persian]

Khani M, Awang RM, Omar D. 2012. Insecticidal effects of peppermint and black pepper essential oils against Rice Weevil, Sitophilus oryzae L. and Rice Moth, Corcyra cephalonica (St.). J Med Plants 11 (43): 97-110.

Khani M, Marouf A, Amini Sh, Yazdani D, Farashiani ME, Ahvazi M, Khalighi-Sigaroodi F, Hosseini-Gharalari A. 2017. Efficacy of three herbal essential oils against rice weevil, Sitophilus oryzae (Coleoptera: Curculionidae). JEOP. 20 (4): 937-950.

Kim SW, Kang J, Park IK. 2013. Fumigant toxicity of Apiaceaeessential oils and their constituents against Sitophilus oryzae and their acetylcholinesterase inhibitory activity. J Asia Pac Entomol 16 (4): 443-448.

Kim SW, Lee HR, Jang MJ, Jang CS, Park IK. 2016. Fumigant toxicity of lamiaceae plant essential oils and blends of their constituents against adult rice weevil Sitophilus oryzae. Molecules. 21 (361): 2-10.

Mahmoudvand M, Abbasipour H, Basij M, Hosseinpour MH, Rastegar F, Nasiri MB. 2011. Fumigant toxicityof some essential oils on adults of somestored-product pests. Chilean JAR. 71 (1): 83-89.

McDonald LL, Guy RH, Speirs RD. 1970. Preliminary evaluation of new candidate materials as toxicants, repellents and attractants against stored-product insects. Marketing Research Report. 882.

McLafferty FW, Stauffer DB. 1989. The Wiley / NBs registry of mass spectral data. Wiley, New York.

Mohammadpour N, Emami S.A, Asili J. 2013. Identification of volatile oil components of Nepeta binaludensis Jamzad by GC-MS and 13CNMR methods and evaluation of its antimicrobial activity. J Essent Oil Bearing Plants (JEOP) 16 (1): 102-107. 
Mozaffarian V. 1998. A dictionary of Iranian plant names. Farhang Moaser Publishers. Tehran, Iran.

Naguib NYM. 2011. Organic vs chemical fertilization of medicinal plants: A concise review of researches. Adv Environ Biol 5: 394-400.

Negahban M, Moharramipour S, Sefidkon F. 2006. Chemical composition and insecticidal activity of Artemisia scoparia essential oil against three coleopteran stored-product insects. J Asia Pac Entomol. 9 (4): 381-388

Negahban M, Moharramipour S. 2007. Fumigant toxicity of Eucalyptus intertexta, Eucalyptus sargentii and Eucalyptus camaldulensis against stored-product beetles. J Appl Entomol 31 (4): 256-261

Obeng-Ofori D, Reichmuth CH. 1997. Bioactivity of eugenol, a major component of essential oil of Ocimum suave (Wild.) against four species of stored-product Coleoptera. Intl J Pest Manag 43 (1): 89-94.

Ogendo JO, Kostyukovsky M, Ravid U, Matasyoh J.C, Deng AL, Omolo EO, Kariuki ST, Shaaya E. 2008. Bioactivity of Ocimum gratissimum L. oil and two of its constituents against five insect pests attacking stored food products. J Stored Prod Res. 44 (4): 328-334.

Ozkan M. 2008. Glandular and eglandular hairs of salvia recognita Fisch. And Mey. (Lamiaceae) in Turkey. Bangla J Bot. 37: 93-95.

Park IK, Lee SG, Choi DH, Park JD, Ahn YJ. 2003. Insecticidal activities of constituents identified in the essential oil from leaves of Chamaecyparis obtusa against Callosobruchus chinensis (L.) and Sitophilus oryzae (L.). Stored Prod Res 39: 375-384.

Prabakar K, Jebanesan A. 2004. Larvicidal efficacy of some Cucurbitacious plant leaf extracts against Culex quinquefasciatus (Say). Bioresour Technol 95: 113-114.

Prakash A, Rao J. 1997. Botanical Pesticides in Agriculture. CRC Press Inc, Boca Raton, FL.
Rahman A, Talukder FA. 2006. Bioefficacy of some plant derivatives that protect grain against the pulse beetle, Callosobruchus maculatus. J Insect Sci 3: 1-10.

Rechinger KH,Hedge IC, Ietwart JH, Jalas J, Mennema J and Seybolu S. 1982. Nepeta, in Rechinger KH ed: Flora Iranica: No 150. Akademische Druck und Verlagsanstalt, Vienna.

Regnault-Roger C, Vincent C, Arnason JT. 2012. Essential oils in insect control: low-risk products in a high-stakes world. Ann Rev Entomol 57: 405-424.

Robertson JL, Russell RM, Savin NE. 2003. LeOra, Software, Poloplus, A User's Guide to Probit or Logit Analysis. Department of Agriculture Berkeley, CA.

Santos FA, Silva RM, Campos AR, Araújo RP, Júnior RCPL, Rao VSN 2004. 1,8-cineole (eucalyptol), a monoterpene oxide attenuates the colonic damage in rats on acute TNBS-colitis. Food Chem. Toxicol. 42: 579-584.

Sarac N, Ugur A. 2007. Antimicrobial activities and usage in folkloric medicine of some Lamiaceae species growing in Mugla, Turkey. Eur Asia J. Bio. Sci. 1: 28-34.

Schultz G, Simbro E, Belden J, Zhu J, Coats J. 2004. Catnip, Nepeta cataria (Lamiales: Lamiaceae) - a closer look: seasonal occurrence of nepetalactone isomers and comparative repellency of three terpenoids to insects. Environ Entomol 33: 1562-1569.

Shaaya E, Kostjukovski M, Eilberg J, Sukprakarn C. 1997. Plant oils as fumigants and contact insecticides for the control of stored-product insects. J Stored Prod Res 33: 7-15.

Venkateshappa SM, Sreenath KP. 2013. Potential Medicinal Plants of Lamiaceae. Amer Intl J Res Formal Appl Nat Sci (AIJRFANS) 3 (1): 82-87.

WHO. 2008. "Traditional medicine" Fact sheet number. 134 (December). World Health Organization, Geneva. 